\title{
THE ROLE OF BEES IN DEVELOPING A LEGAL FRAMEWORK
}

\author{
Ilga Krampuza \\ Mg.iur., Mg.soc.sc., lecturer, researcher, Rezekne Academy of Technologies, Rezekne, \\ Latvia, e-mail: ilga.krampuza@rta.lv
}

\begin{abstract}
The research highlights the need for implementation of sustainable bee population protection. For example, uncontrolled or poorly controlled use of chemicals in agriculture has a direct impact not only on the bee life cycle, but also on the safety and sustainable development of the human environment and on environmental protection as a whole. The aim of the research is to highlight the need to limit and transparently control the use of chemicals in agricultural production in order to protect the safe living environment of humans through the legislation primarily aimed at protecting bees. The main methods used are statistical, systemic, analytical and comparative methods. It is proposed to raise public information activities, as well as to harmonize the regulatory enactments with the right to a favourable environment defined in the Constitution (Satversme) and to prohibit the use of poisonous chemical substances in agricultural production.
\end{abstract}

Keywords: bees, chemicals, environmental protection, regulations, threat to bees.

\section{Introduction}

The research considers the need to protect bees, with emphasis on the need to reduce and monitor the decline in use of toxic chemicals and necessity to supervise the use of toxic chemicals in agricultural production.

With the help of the statistical method, the conclusions are drawn regarding the economic contribution of the bee population to the national economy. Through the systemic approach, the activities of both public and various other organizations in raising and resolving this issue are considered. The comparative method provides an insight into similar issues in Latvia and other countries. Applying the analytical method allows drawing conclusions and making suggestions for solving the problems identified.

The research period covers the experience gained in the previous years, with a particular emphasis on public interest protection activities over the previous two years.

The research hypothesize: the implementation of sustainable bee population protection is directly related to ensuring a safe, healthy human life and protection the environment as a whole.

It has been concluded that protection of the bee population ensures not only the survival of these insects, but is an absolutely necessary precondition for the sustainable development of the human environment.

Ai bitīte, ai bitīte,

Tavu lielu čaklumiņu: 
Tecēj' dienu, tecēj' nakti,

Ne miedziṇa negulēja.

\section{Characteristics of bees, their importance in the human life}

If, for example, when we hear the word 'oak', we associate it with strength, stability, safety, and the word 'bee', in its turn, first of all relates to two meanings: honey and hard-working.

In the dictionary, a bee is described as a hymenopteran that processes flower nectar into honey (Bite, 2017). The most popular is the honeybee (Apis mellifera), which has long been used by humans for honey production. It has long been known among the people that a bee-created product - honey is a natural sweetener that has anti-inflammatory, antiseptic, and immuneboosting properties.

Beekeeping - the agricultural sector - can be described as a type of activity in which beekeepers take care of bee colonies and obtain apiculture products or provide pollination services, that is, bring bee colonies to the agricultural crops for pollination of these plants.

Bees are the main pollinators of cultivated crops and wild plants. About $80 \%$ of the plants on the Earth are entomophilic, which means that they need insects to be pollinated. Honeybees make up about $4 / 5$ of the insects that pollinate plants. The real monetary contribution of bees to this sector is difficult to calculate, however, it has been tried. It is estimated that within the European Union (hereinafter - the EU) honeybees together with wild pollinators (bumblebees, solitary bees, etc.) contribute an additional EUR 22 billion to the agricultural sector each year (Latvijas Biškopības programma 2017. - 2019. g., 2017). Experts point out that bees are extremely important for nature and for the environment. Beekeepers estimate that about $75 \%$ of the food comes from bees. Thus, the environmental benefit provided by a beekeeper is considered to be ten times higher than a beekeeper gains him/herself by producing apiculture products (Biškopība Sēlijā senāk un tagad, 2018)

The European Commission has also recognized that bees are very important for the environment and the economy. Pollinators are estimated to provide pollination for over $80 \%$ of the European cultivated crops and wild plants. Honeybees also provide honey and other beekeeping products, such as pollen, food processing wax, propolis for food technology, and honey jelly is used as a dietary supplement and as a food ingredient (Honey bees, 2017). In addition, the EU is the second largest honey producer in the world after China. Every year, around 600000 beekeepers produce approximately 250000 tonnes of honey (Znotina-Znota, 2018). 
Beekeeping can, to a certain extent, be regarded as a special activity which, first of all, requires considerable experience and skills on the part of a beekeeper, thus recognizing beekeeping as a knowledge-intensive activity. Bees cannot stand neglect, negligence, and alcohol. Secondly, beekeeping requires even "superhuman" skills for working with insects to even find a "common language" with them. In the Latvian folklore, bees are relatable to light, the gods of the upper world, the God, the sons of the God, the daughters of the Sun, and Ūsins - the god of light and spring, symbol of fertility, guardian of horses and bees. Beekeeping is also one of the ways to improve your lifestyle.

Thus, sustainable beekeeping is important both for protection of the insects themselves and even more for the human being in order to preserve the most natural living environment possible, and to provide availability of natural food, thus preserving the human health.

According to the data of the Central Statistical Bureau, there were 103 000 bee colonies registered in Latvia in 2018; 96000 - in 2017 (Lauksaimniecības dzīvnieku skaits gada beigās, 2018). The number of bee colonies have stabilized in the recent years.

\section{Characteristics of threats to bees and of kinds of bees}

The representatives of the United Nations warn on rapid decline in bee numbers in the world, threatening the very existence of many plants and animal species, as these insects pollinate 170000 plant species, which, in its turn, ensures the survival of 200000 animal species (Smiltnieks A., 2018). Therefore, the conclusions are drawn that bees are responsible for about one third of the world's food production and provide jobs for millions of people.

Obviously, with the increase in agricultural production and especially intensive farming, the areas favouring beekeeping are shrinking. Intensive agriculture contributes to poverty - the creation of plant and animal species resulting from the agricultural activities.

In addition, intensive use of agrochemicals adversely affects the diversity of living organisms living in homogeneous conditions, including populations of natural pollinators (Latvijas Biškopības programma 2017.2019.g., 2018). Therefore, a significant role of bees can be identified not only in pollination of crops, but also in maintaining the viability of the whole ecosystem. The presence or absence of bee protection programmes can be seen to have a direct impact on the creation and maintenance of a favourable human environment and vice versa.

Section 115 of the Constitution of the Republic of Latvia stipulates that the State shall protect the right of everyone to live in a favourable environment by providing the information on the state of the environment 
and taking care of its conservation and improvement (Latvijas Republikas Satversme, Latvijas Republikas Saeimas un Ministru Kabineta Ziṇotājs, 1994). Therefore, there is an obligation of the State to establish and ensure an effective environmental protection system (Meire, Čepāne, 2011). It is undeniable that the conservation and development of the bee (human) population is an essential element for the environmental protection system, as well as a set of the regulatory enactments ensuring the development.

First of all, the mortality of bees and other pollinators is related to the human management activities and, above all, to the use of various types of chemicals, habitat loss, pesticides, the development of non-native species and climate change.

The general obligation to limit or exclude the circumstances mentioned in relation to bee mortality follows from the definition of sustainable development as defined in Section 1, paragraph 4 of the Environmental Protection Law (Vides aizsardzības likums, 2006), which includes sustainable development - the integrated and balanced development of public welfare, the environment and the economy, which meets the present social and economic needs of inhabitants and ensures the compliance with the environmental requirements, not endangering the possibility to meet the needs of the future generations, as well as ensures the conservation of the biologic diversity.

For example, the use of neonicotinoid pesticides, which are widely used in insect control, namely imidaclopyr, clothianide and thiamethoxam, is a major problem. It is believed that these chemicals do not deliver the promised crop yields for agriculture, however they cause acute and chronic damage to honeybees, as well as they accumulate in soil and water (Lāce A., 2018).

At the end of 2013, the European Commission imposed restrictions on the use of neonicotinoids, agreeing with the beekeepers' and environmentalists' nearly 20-year efforts to ban these insecticides on crops used by honeybees. A moratorium was announced to conduct in-depth studies on the impact of neonicotinoids on the environment. However, Latvia and several other Member States were allowed to issue emergency permits allowing the use of etched spring rapeseeds. Andrejs Briedis, an expert of the Latvian Fund for Nature (Lāce, 2018), has reasonably concluded that the exception has become a system.

The Plant Protection Service under the supervision of the Ministry of Agriculture issued, on an annual basis, emergency permits to certain farms for the purchase and sowing of neo - nicotinoid - germinated spring rapeseeds. As regards the negative impacts on the public health and the environment, several aspects of implementation are identified as particularly problematic: misuse of emergency authorization procedures, 
increasing use of the confirmatory data procedure, problems of implementation of the precautionary principle - incomplete harmonization of data requirements and methodologies applied in some areas for the evaluation of substances, defining exclusion criteria for these substances (Ziṇojums par augu aizsardzības līdzekḷu regulas (EK) Nr. 1107/2009 ìstenošanu (2017/2128(INI)), 2018).

In general, there is an active debate in Europe on the sustainable use of pesticides and banning of neonicotinoids. These issues are crucial for the environment and human and bee health - in fact, for the human survival. The year 2018 is the last year when farmers can spray fields with neonicotinoids (poisons that kill not only pests but also other insects, including bees). Neonics - systemic pesticides are water soluble, spread throughout a plant, making the entire plant poisonous to insects. Therefore, even a small concentration of these pesticides leads to long-lasting effects. It is believed that if seeds and plants are treated (etched) indoors, nothing much comes out of these neonics and no harm can be caused. However, exactly due to these good properties they are very harmful to bees and other pollinators because, when seeds or seedlings are treated with neonicotinoids, the whole plant becomes harmful to insects, including its secreted juices, nectar, and pollen. Under the sun influence, neonics can degrade in a month time, however if the sun does not reach them, their residues can remain in the soil for more than three years. Neonics not only kill bees, but also distract them, and bees feel like being drunk and can no longer find their way home (Simanovska, 2018).

Although Latvia abstained from voting, the European countries agreed to completely ban three plant protection products of the neonicotinoid group to be used outside in the field - thiamethoxam, imidacloprid, clothianide (Mičāne I., 2018). With this ban, the interests of large landowners who have defended their interest in neonicotinoid use with the aim of maximizing crop yields are enlightened. At the same time, it is incomprehensible why those farmers expressing these interests do not understand that they themselves use this bread, thus adversely affecting their own health and that of others, and of course the bee health. These products will still be allowed to be used in greenhouses (Informativais zinojums, 2018).

In an information report on the attitude of the Republic of Latvia regarding this issue, the Minister of Agriculture at that time specified that in the event of an additional ban on the use of neonicotinoids, Latvia forecasted losses of millions of euros each year for summer rape, potato, fruit trees, carrot, cabbage and softwood samplings growers. However, on the other hand, it was not mentioned that consumers of food, after treatment with pesticides, would be subsequently forced to spend on the use of pharmaceutical business services. 
Some social activists, however, were concerned whether such a ban would save bees, thus British entomologist Dave Gulson rightly said that in the 1940s the mankind used organochlorine pesticides as DDT. When they were banned, farmers switched to pesticides based on phosphoric acid. Then neonicotinoids appeared. This will be followed by something else but equally harmful. If we do not break this vicious circle, there is no hope for a significant step forward in protecting the environment, the expert believes (Buikse, 2018)

There is no doubt that limiting the use of chemicals will help to save bees' lives and at the same time have a positive impact on the health of food consumers. However, it is understandable that the pressure of industrialized agricultural and pharmaceutical businesses, including those making laws, is enormous and invariably systemic.

Therefore, it shall be recognized that the greatest help in ensuring a healthy, sustainable life for bees and humans is in the hands of people themselves. It is very hopeful that a part of the society begins to realize the enormous harm caused to bees by using chemicals in the processing of agricultural products, and ultimately to human health and the environment itself.

According to the cause principle, the damage caused or likely to occur to the environment must be prevented, firstly by eliminating its cause (Meseršmits, Meiere, Ūsinna, 2003). Identifying the causes for clarifying other causes of bee population decline should be recognized as a primary issue. In addition, finding the primary cause relates to the above-mentioned resistance from interested farmers who use in their production substances harmful to bees and consequently harmful to humans, including harmful pesticides. Therefore, civil society has a key role to play in implementing the cause principle. The public involvement, in its turn, requires, firstly, informing the public about the significance of the problem, and, secondly, ensuring the public participation opportunities in relevant decisions making.

It is understood that agricultural activities shall also constantly seek a balance between production and environmental impact, however, based on Section 115 of the Constitution of the Republic of Latvia (Latvijas Republikas Satversme, Latvijas Republikas Saeimas un Ministru Kabineta Ziṇotājs, 1994), the primary consideration must be creation of a favourable living environment for humans, including the right to healthy food, which is fully in line with the "interests of bees" by defending their rights for life. In addition, based on the stipulations of Section 6, Clause 1 of the Environmental Protection Law (Vides aizsardzības likums, 2006), any person may require public authorities and local governments, officials or individuals to cease an activity or omission worsening the environment, if it is harmful to human health or the environment, if it endangers their lives, legal interests or 
property. It follows directly from the above mentioned that individuals have the right to require the State to take active steps to ensure the conservation of bees in so far as they fall within the competence of the State or local authorities. It should also be noted that the bee itself cannot ask for anything.

of course, informing the public also involves organizing unconventional, innovative and modern information activities. For example, since May 20, 2018, the World Bee Day has been introduced by the UN according to the initiative of the Slovenians. It is celebrated worldwide. The purpose of this day is to raise public awareness of the role of bees in sustainable environmental development and in ensuring the biodiversity (Par Pasaules Bišu dienu Lielbritānijā, 2018). The goal of the Bee Day is to highlight their important role and the declining number of bees in the world. More than 10,000 beekeepers are registered in Slovenia, and the local bee species are protected by law (Kūrēns, 2018).

Several research projects have been launched in the EU in the recent years to try to explain the key factors affecting bee health and losses in managed honeybee colonies, which, on the one hand, raise the specific problems at the EU level and, on the other hand, have yielded only results having a recommending nature.

For example, the Super-B project is a cost action, joint research on bees and other pollinators. The project brings together the scientific and society communities involved in pollinator mediation. The decline in the populations of European wild bees and other insect pollinators was assessed within the ALARM project, which also assessed the circumstances contributing to the observed damage, including habitat loss, fragmentation, pesticides, invasive and climate change. Based on this project, the STEP project assesses the impact of pollinator abandonment on agriculture, biodiversity and the wider community. STEP also developed mitigation strategies to ensure that pollinators are protected and managed to provide sustainable pollination services. The COLOSS COST action has established a network of researchers and other stakeholders across Europe to follow the evolution of colony losses and to join the forces in national research programmes to understand and struggle against the major colony losses (Pētniecības projekti, 2018).

It can be concluded that informing the public about preserving the bee (human) living environment nowadays has to relate to the society's new and unprecedented activities, and the state should provide material support for implementation of these opportunities.

The other direction in bee protection relates to an EU directive on chemicals and pesticides designed to protect human health and the environment. For example, Austria has become the first EU-Member State to completely ban the use of the chemical glyphosate. This substance is the main ingredient of the widely used herbicide "Raundap" (Siltnieks, 2018). 
Article 4 of Directive 2009/128/EC states that a purpose of the National Action Plan is to adopt a plan in the Member State that is aimed at setting up quantitative objectives, targets, measures and timetables to reduce risks and impacts of pesticide use on human health and the environment and to encourage the development and introduction of integrated pest management and of alternative approaches or techniques in order to reduce dependency on the use of pesticides (Eiropas Parlamenta un Padomes direktiva 2009/128/EK, 2009), which shall ensure drafting the normative enactments for bee protection.

It is therefore necessary for the legislator to adopt a long-term strategy for improving bee health and population recovery, one of the primary means of which would be a ban on all pesticides which, according to the scientifically proven tests, negatively affect bee health, while developing and promoting safe alternatives for farmers. Until such conditions are adopted, the Law on the Conservation of Species and Biotopes and the Environmental Protection Law shall provide for a timely warning on spraying periods by the farmer intending to use the allowed pesticides in order to prevent damage to bees, while local authorities should be required to control the compliance with the fulfilment of these provisions.

\section{Conclusions and suggestions}

1. Section $7 \cdot{ }^{1}$ „Measures for Ensuring of Favourable Conservation Status of Species and Biotopes" of the Law on the Conservation of Species and Biotopes shall provide the obligation for farmers who intend to use allowed pesticides to inform on the spraying periods all owners of registered honeybee colonies within a radius of two kilometres from the spraying area at least three days before the commencement of spraying works. Section 22 of the Environmental Protection Law „Local Government Control in the Environmental Field" shall provide for the obligation of the local government to perform control by establishing whether farmers who spray their areas comply with the obligation imposed by Section 7.1 of the Law on the Conservation of Species and Biotopes.

2. To prohibit the use of any pesticide that has been scientifically proven to have a negative effect on bee health.

3. To provide effective public information on ensuring the best possible bee living conditions by involving the state in the implementation of this issue both through providing material resources and through its participation in the information process. 


\section{References}

1. BITE. (2017). Retrieved September 20, 2019, from https://lv.oxforddictionaries.com/definition/BITE

2. Biškopība Sēlijā senāk un tagad (2018). Retrieved from https://www.vestnesis.lv/ta/id/20411

3. Buikse, I. (2018). Neonikotinoīdi aizliegti - ar bitēm būs viss kārtībā? Retrieved from http: //ivetabuike.wordpress.com/.../neonikotinoidi-aizliegti-ar-bitem-bus-visskartiba

4. Eiropas Parlamenta un Padomes direktīva 2009/128/EK (2009). Eiropas Savienības Oficiālais Vèstnesis, 309/71.

5. Kūrēns, M. (2018). Pasaulē aizvadīta pirmā bišu diena. Retrieved from https://www.lsm.lv/raksts/dzive--stils/vide-un-dzivnieki/pasaule-aizvaditapirma-bisu- diena.a279097/

6. Honey bees. (2018). Retrieved from https://ec.europa.eu/food/animals/ live_animals/bees_en

7. Latvijas Biškopības programma 2017. - 2019. g. (2017). Retrieved from http://strops.lv/attachments/article/461/Nac_prog_16-19.pdf

8. Latvijas Republikas Satversme (1994). Latvijas Republikas Saeimas un Ministru Kabineta Ziṇotājs, 6.

9. Lauksaimniecības dzīvnieku skaits gada beigās (2018). Retrieved from https://data1.csb.gov.lv/pxweb/lv/lauks/lauks_05Lopk_ikgad/LLG220.px/table /tableViewLayout1/?rxid=dce86984-a965-41cb-9beb-47f0e62130cf; https://data1.csb.gov.lv/pxweb/lv/lauks/lauks_05Lopk_ikgad/LLG220.px/table /tableViewLayout1/?rxid=dce86984-a965-41cb-9beb-47f0e62130cf

10. Lāce, A. (2018). Bišu populācija sarūk. Retrieved from https://www.diena.lv/ raksts/videunturisms/.../bisu-populacija-saruk-14195111

11. Meiere, S., Čepāne, I. (2011). 115.panta komentārs. No: Latvijas Republikas Satversmes komentāri. VIII nodaḷa. Cilvēka pamattiesības. Rīga: Latvijas Vēstnesis.

12. Meseršmits, K., Meiere, S., Ūsin,a, E. (2003). Eiropas vides tiesības. Rīga: Latvijas Universitāte.

13. Mičāne, I. (2018). Bišu glābšanas vārdā Brisele tomēr aizliedz neonikotinoīdu lietošanu tīrumos. Retrieved from http://laukos.la.lv/bisu-glabsanas-varda-briseletomer-aizliedz-neonikotinoidu-lietosanu-tirumos

14. Neonicotinoids: risks to bees confirmed (2018). Retrieved from https://www.efsa.europa.eu/en/press/news/180228, 28.02.2018

15. Par Pasaules Bišu dienu Lielbritānijā (2018). Retrieved from https://lvportals.lv/dienaskartiba/304445-par-pasaules-bisu-dienu-lielbritanija2019

16. Par Latvijas Republikas pozīciju Nr.1 (2018). Retrieved from tap.mk.gov.lv/doc/2018_05/ZMZin_230418.778.doc

17. Par pesticīdu ilgtspējīgu lietošanu un neonikotinoīdu aizliegšanu (2018). Retrieved from

https://www.varam.gov.lv/in_site/tools/download.php?file=files/text/Padomes/ $\mathrm{VKP} / \ldots$

18. Pētniecības projekti (2018). Retrieved from https://ec.europa.eu/food/animals/ live_animals/bees/research_en 
19. Smiltnieks, A. (2018). ANO brīdina par bišu izmiršanas radītajiem riskiem. Retrieved from https://www.lsm.lv/raksts/dzive--stils/vide-un-dzivnieki/ano-bridina-parbisu-izmirsanas-raditajiem-riskiem.a319741/

20. Siltnieks, A. (2018). Austrijā aizliedz herbicīdu glifosātu. Retrieved from https://www.lsm.lv/raksts/zinas/arzemes/austrija-aizliedz-herbiciduglifosatu.a324422/

21. Simanovska, J. (2018). Bitīt, uzrausim pa neonikam! Retrieved from https://www.videsvestis.lv/bitit-uzrausim-pa-neonikam/

22. Vides aizsardzības likums (2006). Latvijas Vēstnesis, 183.

23. Znotinna-Znota, S. (2018). Bites un biškopji: EP deputāti aicina ìstenot ilgterminga izdzìvošanas stratēǵiju. Retrieved from https://www.europarl.europa.eu/ latvia/lv/jaunumi/2018/marts_2018/bites-un-biskopji-ep-deput-ti-aicina-stenotilgtermi-a-izdz-vosanas-strat-iju.html

24. Zinnojums par augu aizsardzības lìdzeklu regulas (EK) Nr. 1107/2009 isstenošanu (2017/2128(INI)) (2018). Retrieved from https://www.europarl.europa.eu/ doceo/document/A-8-2018-0268_LV.html 